\title{
OD VITA MONASTICA K VIA CYRILLOMETHODIANA BENEDIKTÍNSKE FUNDAMENTY CYRILO-METODSKEJ DUCHOVNEJ CESTY MEDZI NITROU A SKALKOU
}

\author{
From Vita Monastica to Via Cyrillomethodiana \\ Benedictine Foundations of Cyrillo-Methodian \\ Spiritual Journey between Nitra and Skalka
}

\author{
Viliam Judák
}

DOI: 10.17846/CL.2021.14.2.14-25

\begin{abstract}
JUDÁK, Viliam. From Vita Monastica to Via Cyrillomethodiana. Benedictine Foundations of Cyrillo-Methodian Spiritual Journey between Nitra and Skalka. The time of Cyrillo-Methodian mission belongs to the most important periods in the histories of Slavic nations. Even nowadays we can still see the fruits of the Mission. Cyrillo-Methodian values and traditions were thanks to the Benedictine monasteries continuously preserved and kept. St. Andrew-Zorard and St. Benedict belonged to most important Benedictine-eremites who lived in the territory of Great Moravia. These monks adopted Syrio-Palestinian ascetic rules of eremic life, which were mostly practised at Oriental territories, from the brothers Sts. Constantine and Methodius. The rules were brought into life as it is mentioned in the Legend of St. Maurus, a contemporary living bishop of Pécs. Places where the Benedictines lived, namely the Monastery of Saint Hypolit at Zobor hill in Nitra and Skalka near the city of Trenčín, have remained important spiritual centres to this day.
\end{abstract}

Keywords: Cyrillo-Methodian mission, Benedictine monasteries, eremites, St. Andrew-Zorard and St. Benedict, asceticism, Legend of St. Maurus, Nitra - Zobor, Skalka

\section{Úvod}

Medzi významné dejinné udalosti slovanských národov patrí predovšetkým obdobie cyrilo-metodskej misie. Jej význam je zretel’ný predovšetkým na poli náboženskom, ale aj občianskom, kultúrnom a spoločenskom a nemožno ho ohraničit len jestvovaním Vel'komoravskej ríše.

Od čias, ked' byzantskí misionári sv. Konštantín (Cyril) a sv. Metod pripútali našich predkov ku krestanskému Rímu, a tým i západnej kultúrno-náboženskej orientácii, stala sa cyrilo-metodská idea po celé naše dejiny ich neoddelitelnou súčastou. Stopy cyrilo-metodstva v našich dejinách upevňovali nás nielen $\mathrm{v}$ jednote $\mathrm{s}$ Rímom, ale prehlbovali aj naše vedomie vlastných dejinných osudov. Jej ovocie takto nachádzame do dnešných čias (Kondrla - Králik 2016, 95).

Pápež Ján Pavol II. spája činnost’ solúnskych bratov s ich duchovným otcom zakladatelom sv. Benediktom z Nursie; v apoštolskom liste Egregaiae virtutis uvádza, čo ho viedlo k takémuto závažnému kroku:

„Európa je totiž, ak sa na ňu dívame zo zemepisného hladiska, aj ovocím dvoch prúdov krestanskej tradície; k nim sa pripájajú tiež dve rôzne, ale súčasne v híbke navzájom sa doplňajúce kultúrne formy. Svätý Benedikt svojím vplyvom objal nielen Európu, predovšetkým západnú a strednú, 
ale prostredníctvom kláštorov svojich duchovných synov prenikol tiež do ostatných svetadielov; je teda akoby v strede tohto prúdu, ktorý vychádza z Ríma, zo stolca nástupcu sv. Petra. U svätých solúnskych bratov vystupuje do popredia najskôr prínos antickej gréckej kultúry a potom význam vplyvu, ktorý mala carihradská cirkev a východná tradícia; táto tradícia hlboko prenikla do duchovného života a kultúry mnohých národov a zemí vo východnej časti európskeho svetadielu. “1

\section{Východná askéza ako spájajúci fenomén benediktínskej a cyrilo-metod- skej misie na Velkej Morave}

So životom solúnskych bratov priamo či nepriamo súvisí pôsobenie benediktínov nanašom území. Benediktíni sú pokračovatel’mi v ich činnosti kristianizácie, a to v šírení krestanskej kultúry. Všimneme si to na živote benediktínov eremitov sv. Andreja-Svorada a Beňadika, ktorí sú v Nitrianskej diecéze uctievaní ako patróni biskupstva. Svorad je i patrónom mesta Nitra (Judák1999, 20).S ich životmi súvisí aj najstaršia zachovaná stredoveká próza, písaná po latinsky, ktorá sa zapodieva priamo slovenským prostredím, presnejšie okolím Nitry a Trenčína. Ide o legendu Vita sanctorum heremitarum Zoerardi confessoris et Benedicti martyris (Marsina 1997, 4143). ${ }^{2}$ Autorom tohto životopisného diela je pätkostolský biskup Maurus.Miesto jeho narodenia nie je známe, no zrejme pochádzal z územia Nitrianska, kde sa narodil začiatkom 11. storočia. Predpokladá sa, že ide o jeho reholné meno; pôvodné meno nie je známe (Kuzmik 1983, 268; Kútnik 1968, 155-172). Ešte pred obsadením Nitrianska a Nitry králom Štefanom I. (1018)bol Maurus novicom v zoborskom benediktínskom Kláštore sv. Hipolyta, v ktorom aj začal scholastikát. Pôvodná zoborská tradícia v súvislosti s týmto kláštorom hovorí o Svätoplukovi († 894) ako pustovníkovi, žijúcom na vrchu Zobor v benediktínskom kláštore - zmieňuje sa o tom český historik Kosmas (Foltýn 2009, 11-16).

Maurus ako mladý scholastik - „puerscholasticus“ - na vlastné oči videl benediktínskeho mnícha Svorada. Stalo sa tak možno pri skladaní jeho rehol’nej profesie do rúk opáta Filipa. Udalost’ na vnímavú dušu mladého scholastika silne zapôsobila.

Roku 1030 sa Maurus stal opátom Kláštora sv. Martina na Panónskej hore (Pannonhalma). Král Štefan I. ho potom asi roku 1036 vymenoval za pätkostolského biskupa (Petrovich 1971, 88-91).

1 Apoštolský list bol vydaný 31. decembra 1980 (Acta Apostolicae Sedis 1981, 258-262). Porovnaj tiež Kocev et al. 2017.

2 Maurovu legendu v priebehu 11. - 15. storočia odpisovali v benediktínskych kláštoroch na slovenskom území, osobitne v Kláštore sv. Hipolyta na Zobore, v ktorom úcta k obidvom pustovníkom zapustila hlboké korene. Najstarší zo zachovaných odpisov pochádza zo 14. storočia. V tomto kódexe je nielen úplná verzia Maurovej legendy, ale aj ofícium „mučeníkov Andreja a Benedikta“. Neúplnú, hoci staršiu verziu nachádzame v Záhrebskom breviári (1273 - 1294). V knižnici kolegiálnej Bratislavskej kapituly sv. Martina bol v minulosti rukopis Maurovej legendy v kódexe z roku 1340, avšak v súčasnosti je nezvestný. Rukopis Maurovej legendy obsahuje aj kódex, ktorý vznikol v 1. polovici 15. storočia v Pasove a teraz je uložený v Bavorskej štátnej knižnici v Mníchove. Z konca 15. storočia pochádza odpis legendy v kódexe z kláštora reholných kanonikov Rougu Cloitre (Rubrae Vallis) pri Bruseli. Uložený je v Královskej knižnici Belgicka v Bruseli. Text odpisu bol blízky neznámemu rukopisu, ktorý v 2. polovici 16. storočia použil Surius v svojom diele Vitae Sanctorum. Základom vydania bollandistov sa stal d’alší rukopis, tzv. korssendocký, napísaný v 90. rokoch 15. storočia v Korssedocku pri Maastrichte v Belgicku. V seminárnej knižnici v Lubline sa tiež nachádzal rukopis Maurovej legendy z 15. storočia, no teraz je nezvestný. Vita Ss. Zoerardi-Andreae et Benedicti od konca 15. storočia patril k často vydávaným stredovekým literárnym pamiatkam. Nájdeme ho aj v zbierke Legendae Sanctorum Regni Hungariae. (Ďalšie vydania pre ich pomerne velkú rozšírenost’ neuvádzam.) 
Ako možno usúdit' z jeho Legendy o sv. Svoradovi-Andrejovi a Beňadikovi, ani po odchode z Nitrianska sa Maurus neprestal živo zaujímat’ o účinkovanie pustovníka Svorada-Andreja. Spriatelil sa s jeho učeníkom a spolupracovníkom Beňadikom, ktorý pravdepodobne pochádzal z Ponitria, a postupne získal od neho mnohé cenné informácie o Svoradovi. Beňadik často prichádzal do Kláštora sv. Martina v Pannonhalme a nadšene rozprával o svojom učitelovi, ako sa uvádza v Maurovej legende. ${ }^{3}$

Maurus bol tiež v stálom kontakte s nitrianskym opátom Filipom, ktorý ho takisto informoval o velmi prísnej askéze pustovníka Svorada-Andreja. Od opáta Filipa sa potom dozvedel nielen o jeho smrti, ale aj o zázrakoch na jeho príhovor a zavraždení jeho učeníka Beňadika na Skalke pri Trenčíne, kde žil podla príkladu svojho učitela. ${ }^{4}$ Beňadik zomrel tri roky po smrti Svorada-Andreja. Rok Svoradovej smrti nie je istý. Jozef Kútnik $(1969,62)$ jeho smrt' datuje do roku 1031 alebo 1032. Beňadik teda zomrel bud' roku 1034, alebo 1035. Józef Tadeusz Milik $(1966,28)$ datuje Svoradovu smrt’ do roku 1034. Pravdepodobnejšie je však datovanie Jozefa Kútnika $(1969,62)$, a to s ohladom na život Beňadika, jeho smrt’ i zázraky, ktoré sa stali pred vysviackou Maura za biskupa, teda pred rokom 1036.

Zoborský opát Filip poslal Maurovi polovicu retaze, ktorú Svorad nosil okolo pása a ktorá mu časom vrástla do tela. Filip ju objavil po Svoradovej smrti.

Výpovede Svoradovho učeníka Beňadika, ako aj opáta Filipa si Maurus starostlivo zaznačoval - práve ony sa neskôr stali podkladom jeho latinskej legendy. Józef Tadeusz Milik (1966, 9 nn.) hodnotí toto úsilie nasledujúcimi slovami: „Hoci Maurus ako pätkostolský biskup písal o udalostiach spred tridsiatich rokov až roku 1064, jeho relácia je predsa bezprostredná a spolahlivá. Podávané fakty má živo v pamäti, pretože si od začiatku osobne ctil pustovníka Svorada a o jeho život i smrt' sa intenzívne zaujímal. Svedčí o tom polovica retaze, ktorú si od opáta Filipa vypýtal hned’ po Svoradovej smrti a nábožne ju opatroval až do roku 1064, ked' ju odovzdal kniežatu Gejzovi.“

Z autopsie síce Svorada len videl pri jeho príchode do Kláštora sv. Hipolyta na Zobore, bol však jeho súčasníkom (i ked’ ovela mladším). Vytrvalo a sústavne zbieral o ňom informácie „z prvej ruky“ a reholnícko-pustovnícke obdobie Svoradovho života zachytil dôkladne a podrobne.

V tejto súvislosti si chceme všimnút predovšetkým askézu, ktorú uvádza Maurus vo svojej životopisnej legende a ktorá sa objavuje u obidvoch pustovníkov. Ona môže byt jasným spojivom medzi obdobím účinkovania solúnskych bratov sv. Konštantína-Cyrila a sv. Metoda na našom území a pokračovaním v ich činnosti, hoci celkom odlišným spôsobom.

Vnútorné prepojenie cyrilo-metodskej misie s mníšskou tradíciou na úrovni teologického myslenia potvrdzuje rovnako nasledujúci pohlad: „Pre Konštantínovu silnú väzbu na Sväté písmo, kázanie, duchovný život a kontempláciu je možné naznačit aj spojnice s monastickou teológiou, ktorá predstavuje zásadný metodologický protipól scholastiky. Vo väzbe na Sväté písmo sa teda Konštantín javí ako verný žiak patristiky a zároveň ako inšpirátor či predchodca monastiky“ (Hlad 2013, 535).

K osobitným črtám pustovníckeho života Svorada-Andreja a jeho spoločníka Beňadika patrí ako to vyplýva z reguly sv. Benedikta z Nursie -, že sa síce u mníchov zdôrazňovala aj práca, ale neuprednostňovala sa manuálna práca. Navyše v tomto prípade Maurus poukazuje na osobitný charakter askézy- na „velké trápenie tela“ (Minárik 1994, 66).

3 V Maurovej legende sa píše: „Ad nostrum ergo monasterium in honorem beati pontificis Martini consecratum, cum iam dictus monachus Benedictus saepe venisset, mihi haec [...] de eius vita venerabili narravit."

4 Táto skutočnost’ sa v Maurovej legende uvádza slovami: „Sed quae sequntur, Philippus abbas mihi constituto narrare consuevit.“ 
Pustovník Svorad-Andrej prišiel na svojrázny spôsob sebatrýznenia: ${ }^{5}$ okolo pása nosil spomenutú železnú retaz, ktorá sa časom vrástla do tela tohto prísneho askétu a pustovníka. ${ }^{6}$ Maurus zaznamenal, že Svorad-Andrej vždy zachovával pôst, aby sa takto posilňoval v duchovnom živote a verne nasledoval Ježiša Krista. Tri dni nejedol celkom nič, a to z lásky ku Kristovi, ktorý sa pre nás stal človekom a na púšti sa postil štyridsat dní. Ked’ sa bližil čas Velkého pôstu, pustovník prevzal od opáta Filipa štyridsat’ orechov ako živobytie na svoj štyridsatdenný pôst.

Táto prax sa nazýva regulou opáta Zosima ${ }^{7}$ „exemplum vitae regularis sub qua Zosimus degebat“; podla nej na Východe dostal každý mních na obdobie pôstu 45 datlí. Tento jasne rituálny výraz pomáhal mníchom vrátane sv. Andreja-Svorada spojit sa s Kristovou obetou. Telesné umŕtvovanie, ktoré bolo obsahom pôstnej praxe, istým spôsobom predstavovalo liturgiu života sv. Andrej-Svorad ju uskutočňoval podla vzoru Krista. Javí sa to ako značne odlišný životný postoj v porovnaní so spôsobom myslenia nihilistov, tvrdiacich, že po tomto živote už nič nenasleduje, preto treba žit dnes, nič neočakávat’ ani nemat’ zrak upretý vpred (Ďatelinka, 2021, 230).

Tento spôsob pôstnej praxe u pustovníka Andreja-Svorada staršia historiografia nevedela správne vysvetlit' (Kútnik s. a., 12). Rudolf Holinka $(1934,319)$ ho napríklad vyhlásil za nejakú „literárnu reminiscenciu“, pretože pokladal za „nehistorické“ uzatvárat z toho závislost” od starých východných anachoretov. Napriek tomu nemožno nevidiet podobne vel'ké úsilie a pracovné nasadenie, aké pozorujeme u Antonija, prvého ruského mnícha z 11. storočia a zakladatela Kyjevsko-pečerskej lavry. U pustovníka Andreja-Svorada sa tažká manuálna práca spájala s dalšími črtami pustovníckeho života: po namáhavej práci si nedoprial primeraný odpočinok a odriekavý spôsob života stupňoval nedostatkom spánku.

Oba smery spôsobu života zasvätených osôb - mníšsky i eremitský -, ktoré sa prejavili aj v živote zoborských mníchov, vznikli v 4. storočí na Východe, presnejšie v egyptskom púštnom prostredí, v kraji nazývanom Thebaida. Neskôr sa rozšírili po celej Byzantskej ríši. Niektorí mnísi sa však neuspokojili ani s eremitským smerom. Túžili po ešte väčšej dokonalosti, a tak sa natrvalo odlúčili od ostatných a žili v úplnej samote ako anachoreti - v stálej modlitbe a tichosti. Išlo o pustovníkov, ktorí sa dalej špecificky mohli nazývat' napr. akoimeti, teda bdejúci, nespiaci, alebo styliti, pretože celé roky svojho pustovníckeho života prestáli na stĺpoch, príp. dendriti, kedže väčšinu života prežili na stromoch (Colombás, 1990, 179-181).

V Ríme vznikli viaceré benediktínske kláštory, napr. Kláštor sv. Bonifáca a Alexia na Aventine, a boli v čulom styku s byzantskými mníchmi. Východní mnísi, ktorí sa vo vel'kom počte usadili na území dnešného Talianska, vychádzali prevažne z eremitského smeru a kládli dôraz na kontempláciu. Sám Konštantín vstúpil v Ríme (868) práve do takéhoto kláštora a prijal meno Kyrillos = Cyril (Vragaš 1991, 68).

Byzantský spôsob mnišskeho života napokon ovplyvnil i celé západné mníšstvo. V 11. storočí pozorujeme na Západe renesanciu pustovníctva. Vplyv eremitského smeru mníšskeho života sa prejavil aj v benediktínskom prostredí zoborského Kláštora sv. Hipolyta, do ktorého okolo roku 1022 prišiel muž menom Svorad. Na základe Maurovej legendy môžeme usudzovat, že vtedy ešte nebol mníchom. Z rúk opáta Filipa prijal postrižiny a obliekol sa do reholného rúcha. Zložil

5 Svedčí o tom správa $\mathrm{v}$ Maurovej legende aj reliéf na stĺpe $\mathrm{v}$ katedrálnom chráme $\mathrm{v}$ Pécsi, na ktorom má pustovník zobrazený okolo pása výrazný železný kruh.

6 Pozornosṫ si zasluhuje francúzska medirytina zo začiatku 17.storočia, ktorá podla Maurovej legendy zobrazuje nočný odpočinok pustovníka Svorada-Andreja v bútlavom strome, do ktorého sú vbité železné kliny. Nad hlavou má zavesenú obruč so štyrmi velkými kameňmi. Na rytine vidiet i čast železnej retaze, ktorú nosil prísny askéta okolo pása, a pri jeho nohách niekol'ko orechov. Autorom medirytiny je Caspar Wussim (1660 - 1700 v Prahe); v súbore obrazov Das Leben der Einsiedler je obraz sv. Svorada označený č. 37.

7 Sýrsky mních sv. Zosimus žil v 6. storočí a vynikal prísnou askézou. 
reholné sluby a prijal meno Andrej. Rozhodol sa pre pustovnícky život, ale najskôr musel dlhší čas zotrvat v kláštore ako mních. S dovolením opáta Filipa sa potom utiahol do pustovne, aby sa mohol oddał’ eremitskému smeru mníšskeho života, ktorý predstavoval jeho vyvrcholenie. ${ }^{8}$

Jozef Kútnik (s. a., 12) dokazuje, že benediktínski mnísi na Vel'kej Morave prevzali od sv. Konštantína a Metoda sýrsko-palestínske a vôbec orientálne eremitské asketické reguly a praktiky. Sv. Metod ako predstavený na maloázijskom Olympe sa s nimi mohol oboznámit u sýrsko-palestínskych mníchov, ktorí unikali pred mohamedánmi a hladal i útočisko $\mathrm{v}$ byzantskej mnišskej enkláve.

Znalec starého východného mníšstva eremitského typu Józef Tadeusz Milik (1966, 65-66; 143, pozn. 109) nie bez vecného dokladu tvrdí, že pod priamou redakciou sv. Metoda sa na Velkej Morave preložila do staroslovenčiny a zaviedla do patrikonu Zosimova Kefalaja, stručný súhrn mysticko-asketických zásad, ktorá sa potom stala akousi metodikou eremitskej askézy. Tento druh askézy sa praktizoval aj v Kyjevsko-pečorskej lavre, kde sa preniesol z Vel'kej Moravy.

Maurova relácia je teda vierohodným, historicky závažným svedectvom o mysticko-asketických praktikách starých eremitov na území Velkej Moravy. Richard Pražák (1988, 71-72) v tejto súvislosti upozorňuje na skutočnost', že sviatok sv. Andreja sa slávil v ten istý deň ako sviatok palestínskeho Zosima, t. j. 30. novembra - Svoradovo prijatie reholného mena Andrej môže preto dokazovat vplyv grécko-byzantského prostredia.

\section{Kláštor sv. Hipolyta v Nitre ako duchovný pokračovatel’ cyrilo-metodskej misie}

Kláštor sv. Hipolyta v Nitre prešiel rôznymi vývinovými štádiami. Ich zaujímavý prehlad uvádza Jozef Kútnik Šmálov (2005, 27-150 a 230-325); rozlišuje niekol'ko etáp jeho existencie:

I. Obdobie benediktínskej eremitskej cely s výraznými iroškótskymi tradíciami (polovica 8 storočia do roku 829) a závislej od Salzburgu.

II. Obdobie filiálneho benediktínskeho kláštora, zriadeného v čase, ked' sa územie Nitry stalo misijným územím Pasovského biskupstva a biskup Reginhard vyvinul na ňom intenzívnu misionársku činnost'. Misionárska cela benediktínov na Zobore sa pravdepodobne v rokoch 830 - 855 premenila na filiálny kláštor s patrocíniom materského opátstva.

III. Za Svätopluka ako údelného kniežata v Nitre sa Kláštor sv. Hipolyta osamostatnil a pretvoril na opátstvo s výslovným interným a externým misijným poslaním. Kandidáti mohli pochádzat’ už aj z domáceho prostredia. Liturgickou rečou bola latinčina, katechizácia však prebiehala v ludovom jazyku. Toto obdobie spadá približne do rokov $856-865$.

IV. V období pôsobenia byzantskej misie, resp. v rokoch 865 - 899, sa benediktínom na Zobore otvorili vel'ké možnosti na okolitých územiach pohanských slovanských kmeňov. Sv. Konštantín a Metod si získali nitrianskych benediktínov, ktorí mali inštitúciu vysunutých ciel v teréne mimo vlastného kláštora, a oboznámili ich so sýrsko-palestínskou eremitskou regulou. Je možné, že v kláštornom kostole a eremitských oratóriách, vyňatých spod jurisdikcie biskupa a archipresbyterov, sa konala bohoslužba v staroslovenskom jazyku. Tu mohli nájst̉ refugium i žiaci solúnskych bratov, a to dovtedy, kým Metod, už ako moravský arcibiskup a pápežský misijný legát, neprevzal správu velkomoravských kostolov a nezačal oficiálne cirkevne aj štátne organizovat misie v susedných oblastiach. Niektorí, napr. Gorazd, sa mohli po Metodovej smrti roku 885 uchýlit' do benediktínskych kláštorov. $\mathrm{V}$ tomto období nastali historicky prajné podmienky na vytvorenie filiálnych kláštorov združených s arciopátstvom na Zobore.

8 Maurus o tom píše: „[...] heremi solitudinem subintravit.“ 
V. Nasledujúce obdobie trvalo počas 10 . storočia až do prvej štvrtiny 11. storočia, ked' sa pod patronáciou dynastií v utvárajúcich sa ríšach - Přemyslovcov v Čechách, Arpádovcov v Uhorsku, Piastovcov v Pol’sku a Rurikovcov v Kyjevsku - zakladali kláštory nového, unifikovaného latinského typu v Břevnove, na Panónskom vrchu, v Týnci pri Krakove. Kyjev sa odklonil od Západu a priklonil sa $\mathrm{k}$ Východu. Benediktíni $\mathrm{z}$ arciopátstva na Zobore a pridružených kláštorov pokračovali s novým rozmachom v predošlej zdarnej misionárskej činnosti.

VI. Po pripojení Nitry k Uhorsku sa Kláštor sv. Hipolyta na Zobore za opáta Filipa zmenil z cyrilo-metodského typu na latinský typ. Tento prechod bol pokojný a rýchly. Možný bol i preto, lebo opátstvo na Zobore malo od čias Cyrila a Metoda viacrečový ráz: vyučovalo sa v ňom nielen $\mathrm{v}$ domácom jazyku, ale aj latinsky, grécky, staronemecky, ba začiatkom 10. storočia aj mad’arsky. Kňazi mnísi (literáti) zoborského arciopátstva boli stredovekými polyglotmi. Toto obdobie trvalo až do zániku benediktínskeho kláštora na Zobore (1468), resp. do jeho premeny na kamaldulský kláštor (1691). Kamalduli v ňom pôsobili až do zrušenia Jozefom II. (1782).

Zásluhou biskupa Karola Kmetka bol kláštor roku 1937 obnovený a stal sa majetkom misionárov Božieho slova - SVD (Branecký 1945, 19-24). V súčasnosti sa v jeho priestoroch čiastočne nachádza Špecializovaná nemocnica sv. Svorada.

\section{Opátstvo na Skalke pri Trenčíne ako locus východo-západnej eremitskej tradície a jeho misijný význam v dejinách Slovenska}

Beňadik vstúpil do benediktínskeho Kláštora sv. Hipolyta na Zobore a neskôr ho pridelili Svoradovi za pomocníka v starobe a učeníka. Po smrti svojho učitela sa rozhodol bývat na tom istom mieste - tri roky podla jeho príkladu viedol velmi prísny život. Zmieňuje sa o tom životopisná Maurova legenda, no bližšie miesto neurčuje. Starobylá tradícia dosvedčuje, že išlo o Skalku pri Trenčíne. Tu Beňadika prepadli zbojníci, zviazali ho a hodili do rieky Váh. Ludia dlho hladali jeho telo, ale bez výsledku. Zbadali však, že orol po celý rok sedáva na brehu Váhu, akoby niečo pozoroval. A skutočne: našli telo, ktoré bolo po roku neporušené, akoby bol Beňadik zomrel len nedávno. Jozef Kútnik $(1968,63)$ vidí skôr politické než lúpežné príčiny jeho smrti; podla neho vrahovia prišli z moravskej strany. Už roku 1208 však stál na tomto území kostol zasvätený sv. Beňadikovi, ako to uvádza listina šlachtica Tomáša - za hraničnú čiaru chotára obce Skala udáva Kostol sv. Beňadika na Skalke (Marsina 1991, 116).

Hoci existujú zmienky o tom, že Beňadik podobne ako Svorad pochádzal z polského územia (Hodál 1928, 44-77)9 , viacerí, a to i znalec v tejto oblasti opát Ludovít Stárek (1852, 149), poukazujú na skutočnost', že Beňadik nemohol byt Poliakom, pretože nevedel nič o živote Svorada v Polsku. Ak by vedel, isto by o tom porozprával Maurovi, ktorý sa podrobne zaujímal o život pustovníka Svorada-Andreja. Historik Michal Lacko zastáva názor, že Beňadik bol Slovák a pochádzal z Ponitria (Bagin 1992, 28); dnes sa táto mienka všeobecne prijíma aj zo strany odbornej verejnosti.

Zbierka svätcov Uhorska označuje Beňadika za Považana: „S. Benedictus Vageus, eremita in Hungaria“ - sv. Beňadik Vážsky (Acta Sanctorum 1868, 329). Potvrdzuje to i skutočnost', na ktorú upozorňuje rektor jezuitského kláštora v Trenčíne Ladislav Vid. Uvádza, že v okolí Trenčína a Skalky je uctievaný a spomínaný len Beňadik - „populus Trenschini in Skalka solius Benedicti nomen circumfert“ (Buday 1924, 6). Tradícia tiež zachovala, že si pltníci, plaviaci sa

9 Hodál s. a., Hl. III, 44-45. Ide o celoživotné dielo Dr. Juraja Hodála (1888 - 1963), stredoškolského profesora, uložené v archíve Biskupského úradu v Nitre. Rukopis má cca 1500 strán. Porovnaj tiež Hodál 1928, 44-77. 
okolo Skalky, uctievali sv. Beňadika ako svojho patróna a ochrancu a prosili ho o pomoc a ochranu zvláštnou modlitbou. ${ }^{10}$

V benediktínskom prostredí Uhorska koncom 11. storočia kult sv. Beňadika prevýšil kult sv. Svorada-Andreja. Neujal sa však v okolitých slovanských krajoch. U sv. Beňadika sa od začiatku stala miestom jeho úcty Skalka, miesto jeho umučenia. U sv. Svorada-Andreja to bola Nitra, miesto jeho pochovania. Telo sv. Beňadika uložili v nitrianskom Chráme sv. Emeráma, už vtedy označeného za baziliku, a to v tom istom hrobe, v ktorom bol pochovaný sv. Svorad-Andrej. Potvrdzuje to aj rektor Ladislav Vid v druhej polovici 17. storočia (Acta Sanctorum 1868, 327): „Nitriae major fit memoria s. Andreae Zoerardi, imo populus solius Zoerardi nomen circumfert, sicut Trenchini in Skalka solius Benedicti.“ Odvtedy si ich veriaci lud uctieva ako svätcov. Oficiálne ich kult potvrdil pápež Gregor VII. roku 1083, a to spolu s inými uhorskými svätcami: sv. králom Štefanom, jeho synom sv. Imrichom a čanadským biskupom sv. Gerardom. ${ }^{11}$

Najväčšia čast’ relikvií obidvoch svätcov je uložená v Pálffyho relikviári z roku 1674, ktorý sa dnes nachádza v oltári Katedrály-Baziliky sv. Emeráma v Nitre.

Nitriansky biskup Jakub I. vo fundačnej listine Opátstva - Sancti Benedicti - na Skalke z roku 1224 ako dôvod, prečo práve na tomto mieste zakladá opátstvo k úcte sv. Beňadika, udáva zjavné stopy mučeníctva nájdené v jaskyni: „[...] in spelunca quae vulgo Scala dicitur, ubi etiam sanguis eiusdem martyris usque in hodiernum diem perfusus in pariete speluncae esse dinoscitur" (Marsina 1971, 216).

Skalka sa vd’aka pôsobeniu obidvoch pustovníkov, no predovšetkým sv. Beňadika, postupne stala pútnickým miestom. Dnes možno povedat', že ide o najstaršie nemariánske pútnické miesto vtedajšieho Uhorska a významné duchovné centrum Slovenska po celé storočia.

Hmotné zabezpečenie novozriadeného opátstva bolo pomerne malé; išlo o malý kláštor, v ktorom mohlo žit len niekol'ko mníchov. To viedlo panovníka Belu IV. k rozšíreniu majetku kláštora (Vurum 1835, 168-170; Marsina 1997, 94). Opátstvo od svojho založenia až do začiatku 16. storočia spravovali benediktíni (Marsina 1997, 96-98) a bolo duchovným centrom Považia. Jeho šlachetné poslanie však narúšali časté vojnové nepokoje. Počas nájazdov husitov na Slovensko bol roku 1431 dobytý Trenčín a s najväčšou pravdepodobnostou bol poškodený aj kláštor na Skalke (Stránsky 1933, 163).

Roku 1528 vojská Ferdinanda Habsburského dobyli Trenčiansky hrad a majetok kláštora bol použitý ako žold pre cisárskych vojakov. Správu opátstva prebrali nitrianski biskupi. Prvým opátom po vyhnaní benediktínov sa stal Štefan Podmanický. Patronátne právo nad opátstvom dostal 29. novembra 1528 a prešlo aj na jeho nástupcov (Cserenyey 1933, 182). Panovník Ferdinand I. listinou z 22. septembra 1553 potvrdil správcovi diecézy (nebiskupovi) Františkovi Turzovi - ako i jeho nástupcom na nitrianskom stolci - hodnost’ opáta v Skalke (Branecký 1929, 30).

Nitriansky biskup Ján Püsky (opátom na Skalke bol od 9. novembra 1637) so súhlasom krála Ferdinanda III. a ostrihomského arcibiskupa Juraja Lipaya daroval 28. októbra 1644 opátstvo jezuitom (Cserenyey 1933, 215). V darovacej listine o. i. píše: „Rozhodli sme sa, že opátstvo sv. Beňadika, ležiace pri rieke Váh v Trenčianskej župe a Nitrianskej diecéze, všeobecne Skalkou zvané, odovzdáme otcom Spoločnosti Ježišovej“ (Branecký 1929, 36-37).

10 Svedčia o tom napr. básne Pieseň plavecká, uverejnená v časopise Orol tatranský roku 1921, alebo Sen o Skalke od Jozefa Gálika, publikovaná roku 1924 v diele Jozefa Budaya Život sv. Andreja a Benedika, slovenských pustovníkov.

11 V orácii hahotského sakramentára sa sv. Beňadik vzýva ako „tocius nostre gentis povisor“ a jemu sa pripisuje „multimoda miracularum tuitio“. Sekréta toho istého sakramentára sv.Svorada-Andreja tituluje len „patronus noster“. Ich kult bol v niektorých oblastiach jednotlivý; v liturgickom ofíciu od kanonizácie boli slávení spoločne. 
V Trenčíne sa jezuiti nemohli usadit pre nesúhlas mestskej rady. Hoci mali v tomto meste možnost̉ náboženských prejavov viaceré spoločenstvá, pre katolíkov v ňom platil prísny zákaz - „solo Religionis Catholicae exertitio excluso“. Preto si zvolili bývalé benediktínske Opátstvo sv. Beňadika na Skalke, do ktorého prišli roku 1645. Samozrejme, ich túžbou bolo dostat sa do Trenčína, ale to sa im podarilo až 2. decembra 1646 (Branecký 1929, 42).

Prvým jezuitským predstaveným na Skalke sa stal Martin Fábri, Chorvát, s ktorým spolupracoval Daniel Zedník, Slovák, rodák z Pruského (Krapka - Mikula 1990, 116). Hodnotenie pastoračnej činnosti zaznamenal jezuita Martin Fábri nasledujúcimi slovami: „Katolíckemu ludu poskytujeme pokrm učenia Kristovho čiastočne v kostolíku Skalky, čiastočne a najmä v kostolíku Panny Márie, postavenom na strmej skale pri Váhu, odkial’ zhodili svätého Benedikta mučeníka do rieky. Sem chodievajú katolíci z mesta v nedelu a sviatok, lebo evanjelici nestrpia katolíckeho kňaza v Trenčíne“ (Krapka - Mikula 1990, 116).

Začiatky tejto práce na katolíckej obnove horného Považia boli tažké a spojené s velkými prekážkami. Plody apoštolskej horlivosti však postupne dozrievali a rady veriacich rástli nielen tu, ale aj na okolí. Na Skalke mohutnel nábožný spev zhromaždených veriacich po slovensky - „idiomate slavonico“ (Krapka - Mikula 1990, 116).

Jezuiti sa popri mnohorakej pastoračnej a akademickej činnosti starali tiež o hmotné zveladenie bývalého benediktínskeho opátstva. V rokoch 1653 - 1657 postavili v Trenčíne kostol zasvätený sv. Františkovi Xaverskému a v nasledujúcich rokoch, hned’ po stavbe jezuitského kláštora v Trenčíne, začali so stavebnými prácami na Skalke. V rokoch 1667 - 1669 vybudovali v blízkosti polozrúcaného starého kláštora benediktínov nový kláštor (Branecký 1929, 54-56).

Neblahé pomery labansko-kuruckých vojen sa odrazili v Trenčíne aj na Skalke začiatkom 18. storočia. Bolo treba opät pristúpit $\mathrm{k}$ rozsiahlym stavebným úpravám, pretože 14 . mája 1708 lahlo popolom mesto a úplne vyhorel i jezuitský kostol v Trenčíne (J. V. G. 1940, 56).

Starostlivost̉ členovia Spoločnosti Ježišovej preukazovali aj dvojvežovému kostolíku Malej Skalky, zasväteného k úcte Panny Márie. Najskôr išlo o Kaplnku sv. Doroty, ktorú dal vystavit’ gróf Juraj Turzo roku 1520, ako je zaznačené v opise pozemkov: „Ad templum velut in urbario refertur S. Dorotheae“; tiež možno nájst’ záznam: „prius Capella erat S. Doroteae“ (Branecký, 1929, 65-65).

Kaplnka pôvodne nemala vežu. Až roku 1713, ked' ju jezuiti renovovali, pristavili k nej vežu. Roku 1745 rozšírili kaplnku na terajšiu podobu a pristavili dve veže. Trenčania do tohto kostola chodievali v rokoch 1645 - 1646 na bohoslužby, pretože bol bližšie k mestu ako Velká Skalka.

Aj ked' sa jezuiti prestahovali do Trenčína, o kostol sa nadalej starali. V tomto čase sa konávali procesie na Skalku, a to na sviatok sv. Marka, na druhý krížový deň a mariánske sviatky. Hlavným sviatkom Skalky bolo Nanebovzatie Panny Márie. Roku 1679 dal Michal Škerlec, rektor jezuitov, postavit nový oltár a zasvätil ho Čenstochovskej Panne Márie, ktorej úcta bola vtedy velmi rozšírená (Branecký 1929, 66-68).

Počas kuruckých vojen bol kostol poškodený a po roku 1711 bola potrebná jeho dalšia rekonštrukcia. Roku 1749 v ňom postavili Boží hrob a na Velký piatok sa tu konávali procesie. Neskôr postavili na Malej Skalke i kalváriu so štrnástimi stanicami (1676) (Branecký 1929, 70-72).

Plodný duch jezuitov tvorí jej významnú minulost'. Kláštor predstavoval dar duchovného, vzdelanostného a všeobecného kultúrneho vzrastu nielen pre jeho obyvatel’ov, ale aj pre celé Považie, ba značnú čast’ Slovenska. Bol ohniskom evanjelizácie i duchovnej a materiálnej kultúry. Jezuiti tu pôsobili do svojho zrušenia roku 1773 (Krapka - Mikula 1990, 286).

Po ich odchode posvätné miesto poznačili vojny a postupne pustlo. V 18. storočí boli kláštor aj kostol zničené. Na dlhý čas sa premenili na zrúcaniny, avšak zbožný lud ani tak na toto miesto neprestával putovat' a konat' tu pobožnosti. Konečne roku 1853 bol z milodarov veriacich na Malej 
Skalke znovu zreštaurovaný kostol, a to zásluhou trenčianskeho farára a opáta Ludovíta Stáreka (Judák 1993, 61).

Po nasledujúcom spustošení a opätovnej celkovej rekonštrukcii bol kostol 13. júla 1924 posvätený nitrianskym biskupom Karolom Kmetkom za prítomnosti spišského biskupa Jána Vojtaššáka a účasti 30000 pútnikov. Pri tejto príležitosti bolo znovu zverejnené vyhlásenie, ktoré vzniklo 13. februára 1921 pri konsekrácii troch biskupov v Nitre. Práve vtedy totiž vznikla myšlienka, aby sa bývalé benediktínske opátstvo stalo „našou národnou katolíckou svätyňou a ohniskom nášho cirkevno-národného života“" (Belás 1991, 43-44).

Tento celkový zámer so Skalkou sa však napokon pre mnohé príčiny nerealizoval. Vojnové udalosti rokov 1939 - 1945 neobišli ani Skalku. Oprava kostola bola ukončená slávnostou, konanou v nedelu 22. júla 1951. Slávnostnú svätú omšu celebroval nitriansky administrátor biskup Eduard Nécsey (Judák 2012, 167).

Nemožno obíst' ani skutočnost', že ateistický režim sa usiloval získat toto miesto a využívat' ho výlučne na kultúrne účely, teda zbavit’ ho akýchkolvek náboženských prejavov, ako ani fakt, že každoročne - vždy „zhodou okolností zdevastované (Maturkanič et al 2021, 54). Svedčí o tom Historia domus parafia Skaliensis ${ }^{12}$ a korešpondencia medzi miestnym farským úradom, biskupským úradom a štátnymi úradmi v priebehu 60. a 70. rokov 20. storočia. Počas niektorých rokov (1972 - 1974) boli púte dokonca zakázané, a to údajne „kvôli bezpečnosti pútnikov“. Duchovný správca Skalky musel tiež často zápasit s vandalizmom - objavoval sa najmä na Vel'kej Skalke, ale nebol ušetrený ani kostol či pútnický dom. Incidenty sa zvyčajne „nevyšetrili“ (Čergetová - Tomanová et al. 2021, 543-546).

K zmene situácie a novej perspektíve Skalky došlo až po zmene spoločenského systému, a to aj vdaka duchovnému správcovi Mgr. Stanislavovi Strapkovi (†2017), honorárnemu dekanovi, ktorý pôsobil na Skalke od roku 1996, teda 18 rokov (Schematizmus Nitrianskej diecézy 2010, 204). Jeho nástupca Mgr. Peter Beňo, pôsobiaci na Skalke od roku 2014 (Schematizmus Nitrianskej diecézy 2020, 158; 24. apríla 2021 bol konsekrovaný za pomocného nitrianskeho biskupa), pokračoval vo zveladovaní tohto pútnického miesta.

S rovnakým zámerom bol roku 2011 zriadený Investičný fond Beňadik. Roku 2014 bola vybudovaná krížová cesta. Prebehla oprava exteriéru aj interiéru pútnického kostola, ktorý bol vyhlásený za diecéznu svätyňu a konsekrovaný spolu s novým oltárom a liturgickým zariadením 7. mája 2016. V rokoch 2018 - 2019 bol vystavaný Dom sv. Beňadika, ktorý pútnikom ponúka možnost’ ubytovania, a bolo upravené okolie pútnického miesta. Zreštaurovaná bola aj Velká Skalka, na ktorej je počas turistickej sezóny zabezpečená sprievodcovská služba.

Skalka je - ako každé pútnické miesto - predovšetkým miestom modlitby a duchovného obohatenia. Denne sa tam preto konajú bohoslužby, organizujú sa púte, duchovné obnovy a iné podujatia, napr. každoročné medzinárodné tvorivé stretnutie umelcov Ora et ars či pútnický kongres Svitanie. Všetky tieto aktivity sa usilujú o to, aby na tomto vzácnom mieste obohatili a duchovne nasmerovali dnešného človeka k evanjeliovým hodnotám. ${ }^{13}$

12 Historia domus parafia Skaliensis, ktorá má 322 strán a bola zostavená Karolom Rumpelom, farárom na Skalke, sa začína rokom 1773, ked' zodpovednost' za pútnický kostol prevzal skalský farár. Bolo to $\mathrm{v}$ čase zrušenia rehole jezuitov, ktorí sa dovtedy starali o toto miesto - pôsobili tu od roku 1644, ako už bolo uvedené. Kronika sa končí životopisom farára Karola Rumpela, ktorý pôsobil na Skalke do 3. augusta 1983. Zomrel 24. mája 1986 v Trenčíne-Orechovom, kde je aj pochovaný.

13 Pútnické miesto má svoj pedagogický význam. Porovnaj: Tkáčová et al 2021. 


\section{Záver}

Cyrilo-metodské hodnoty, prijaté a zachovávané aj v benediktínskych kláštoroch, ktoré reprezentujú osobnosti sv. Svorada-Andreja a sv. Beňadika, sa stali „ohňom, čo tlel pod popolom na spálenisku zanechanom vpádmi, plenmi a inými skúškami“ (Tomko 1991, 54). Len vd’aka nim mohlo Slovensko po strate štátnej samostatnosti a v susedstve silnejších etník nestratit vlastnú identitu v búrlivých prúdoch dejín, ktoré sa celé stáročia hnali cez naše územie.

Ak platí, že historická cesta exodu, spojená so zjavením na Sinaji, zmluvou a liturgickou bohopoctou, ktoré konštituujú akúsi vnútornú krajinu, je nevyhnutnou podmienkou nadobudnutia vonkajšej krajiny ${ }^{14}$, potom i cyrilo-metodská cesta, nielen tá vonkajšia, ale najmä vnútorná, ktorej cielom je nový exodus, stretnutie Boha na vrchu Zobor a na Skalke, obnovenie zmluvy, aktívne prežívaná liturgia (čo predstavuje d’alšiu vel’mi silnú spojnicu cyrilo-metodskej a benediktínskej tradície), nadobúda štátotvorný a národotvorný význam. Možno preto vyjadrit’ presvedčenie, že cyrilo-metodská viera uchovávaná v benediktínskej tradícii na týchto miestach nás môže naučit, „ako nastolit’ správnu, t. j. pozitívnu cestu budovania nášho národa, ktorý neustále hladá tú správnu identitu starého kontinentu" (Maturkanič 2013, 623). Nitra i Skalka ako centrá religiózneho cestovného ruchu na Slovensku reflektujú historicky pevne zakorenenú religiozitu obyvatelov (Krogmann - Kramáreková - Petrikovičová 2020, 86). Obidve lokality sú súčastou Európskej kultúrnej cesty sv. Cyrila a Metoda, ktorá bola certifikovaná v roku 2021 Radou Európy. ${ }^{15}$

\section{REFERENCES}

Acta Sanctorum. 1868. Acta Sanctorum. Tom. IV. Paris - Romae.

Acta Apostolicae Sedis. 1981. Acta Apostolicae Sedis 73. Città del Vaticano.

Bagin, Anton. 1992. Sv. Benedikt. In Posol LXXI/9, 28.

Belás, Ladislav. 1991. Vysviacka pred 70 rokmi. In Nitra. kultúrno-spoločenský mesačník XV/4, 43-44.

Branecký, Jozef. 1945. Krátke dejiny zuborského kláštora a opátstva. Žilina.

Branecký, Jozef. 1929. Skalka podla historických dokumentov. Trnava.

Buday, Jozef. 1924. Život sv. Andreja a Benedika, slovenských pustovníkov. Trnava.

Colombás, Maria García. 1990. Il monachesimo delle origini. Tomo 2 Spiritualità. Milano.

Cserenyey, Štefan. 1933. Pamätnosti z dejín Nitrianskeho biskupstva od roku 1500. In Dejiny biskupstva nitrianskeho. Trnava.

Čergetová - Tomanová, Ivana - Maturkanič, Patrik - Hlad, Lubomír - Biryuková, Y. - Martin, Jose, Garcia. 2021. Spirituality and Irrational beliefs of movement activities in Slovaks and Czechs. In Journal of Education Culture and Society 12/2, 539-549.

14 Ide o ideu, ktorú ponúka Joseph Ratzinger v diele Duch liturgie. Uvažuje o dvoch cieloch exodu - jeden z nich je bohopocta, ktorá neostáva len $\mathrm{v}$ rovine duchovnej, ale ovplyvňuje i dejinné reálie, teda zaujatie zaslúbenej zeme, čo je druhý ciel'exodu:„Čo to znamená pre nás, pre otázku o dvoch cieloch liturgie? Môžeme vidiet', že to, čo sa udialo na Sinaji pri zastávke počas putovania púštou, predstavuje prvoradý zmysel zaujatia krajiny. Sinaj nie je len medzistanicou, takpovediac zastávkou na ceste k vlastnej krajine, ale ustanovuje akúsi vnútornú krajinu, bez ktorej by vonkajšia zostala neobývatel'nou. Len preto, že sa Izrael stáva prostredníctvom zmluvy a v nej obsiahnutého práva ludom, že prijal spoločnú formu pravého života, len preto môže dostat do vlastníctva krajinu. Sinaj zostáva prítomný aj v prislúbenej krajine; a v miere, v akej sa stráca jeho prítomnost', v tej miere Izraeliti zároveň strácajú svoju krajinu " (Ratzinger, 2005, 14).

15 https://www.cyril-methodius.cz/. 
Ďatelinka, Anton. 2021. Rituálne vyjadrenie krestanskej viery v kontexte moderny a postmoderny. In Duchovný pastier 102/5, 225-233.

Foltýn, Dušan. 2009. Pražský děkan Kosmas a jeho správa o údajném předchůdci benediktínského opatství na Zoboru. In Monumentorum tutela. Ochrana pamiatok 21, Bratislava, 11-16.

Hlad, Lubomír. 2013. Prvky trojičnej teológie v diele Život Konštantína-Cyrila. In Lukáčová, Martina et al. Tradícia a prítomnost misijného diela sv. Cyrila a Metoda. Nitra, 533-541.

Hodál, Juraj. 1928. Dvaja slovenskí pustovníci v XI. storočí. In Z minulosti Slovenska. Sväzok 8. Bratislava, 44-77.

Hodál, Juraj. s. a. Sv. Svorád a Benedík, pustovníci na Slovensku. (Manuscript).

Holinka, Rudolf. 1934. Sv. Svorad a Benedikt, světci Slovenska. Bratislava.

J. V. G. 1940. Skalka - jezuiti - Slovensko. Trnava.

Ján Pavol II. 1981. Apoštolský list Egregaiae virtutis. In Judák, Viliam - Liba, Peter. 2012.

Od Petrovho stolca k Vel'kej Morave. Pápežské dokumenty o sv. Cyrilovi a Metodovi z rokov 868 - 2012. Trnava.

Judák, Viliam. 1993. Hviezdy slovenského neba. s.l.

Judák, Viliam. 1999. Svätý Svorad, patrón mesta Nitry. Nitra.

Judák, Viliam. 2012. Vo všetkom láska. Životopisný profil ThDr. Eduarda Nécseya. Nitra.

Judák, Viliam. 2011. Z múdrosti našich otcov. Sv. Beňadik a Skalka. Nitra.

Kondrla, Peter - Králik, Roman 2016. Špecifiká misie solúnskych bratov a ich aktualizačný poteciál

[The specifics of mission of the thessalonian brothers and the potential for their actualization].

In Konštantínove listy [Constantine’s Letters] 9/2, 90-97.

Kocev, Pavle - Kondrla, Peter - Králik, Roman - Roubalová, Marie. 2017. Sv. Kliment Ochridský a jeho pôsobenie v Macedónsku [St. Clement of Ohrid and his activities in Macedonia]. In Konštantínove listy [Constantine's Letters] 10/2, 88-97.

Krapka, Emil - Mikula, Vojtech. 1990. Dejiny Spoločnosti Ježišovej na Slovensku 1561 - 1998. Cambridge On. Kanada.

Krogmann, Alfred - Kramáreková, Hilda - Petrikovičová Lucia. 2020. Religiózny cestovný ruch v Nitrianskej diecéze. Nitra.

Kútnik, Jozef. s. a. Misie benediktínov-eremitov z Opátstva sv. Hypolita na Zobore pri Nitre. (Manuscript).

Kútnik, Jozef. 1968. O pôvode pätkostolského Maura. In Spiš 2, 155-172.

Kútnik, Jozef. 1969. O pôvode pustovníka Svorada (k počiatku kultúrnych dejín Liptova). In Nové Obzory 11. (Odtlačok). Košice.

Kútnik Šmálov, Jozef. 2005. Krestanský stredovek Slovenska. Bratislava.

Kuzmik, Jozef. 1983. Slovník starovekých a stredovekých autorov, prameňov a knižných skriptorov so slovenskými vztahmi. Martin.

Legendae Sanctorum Regni Hungariae. Legendae Sanctorum Regni Hungariae 1484 a 1486. Strassburg.

Marsina, Richard. 1997. Benediktínske opátstvo Skalka (Skala). In Skalka pri Trenčíne. Miesto legiend a pútí. Zborník z vlastivedného seminára 23. mája 1996. Trenčín, 94-101.

Marsina, Richard. (ed.). 1991. Codex diplomaticus et epistolaris Slovaciae 1. Bratislava.

Marsina, Richard. (ed.). 1997. Legendy stredovekého Slovenska. Ideály stredovekého človeka očami cirkevných spisovatelov. Budmerice.

Maturkanič, Patrik. 2013. Velikost života víry svatých slovanských věrozvěstů Cyrila a Metoděje a jejich vliv na evropského člověka žijícího na počátku 21. století. In Lukáčová, Martina et al. Tradícia a prítomnost' misijného diela sv. Cyrila a Metoda. Nitra, 621-626. 
Maturkanič, Patrik - Čergetová - Tomanová, Ivana - Kondrla, Peter-Kurilenko, Viktoria - Martin, José, Garcia. 2021. Homo culturalis versus Cultura animi. In Journal of Education Culture and Society 12/2, 51-58.

Milik, Józef Tadeusz. 1966. Swiety Swierad. Sant Andrew Zoerardus. Roma.

Minárik, Jozef. 1994. Z klenotnice staršieho slovenského písomníctva. Bratislava.

Petrovich, Ede. 1971. Szent Mór Pécsi püspök. In Vigilia 02/085, 88-91.

Pražák, Richard. 1988. Legendy a kroniky koruny uherské. Praha.

Ratzinger, Joseph. 2005. Duch liturgie. Trnava.

Rumpel, Karol. s. a. Historia domus parafia Skaliensis. (Manuscript).

Schematizmus Nitrianskej diecézy. 2010. Schematizmus Nitrianskej diecézy 2010. Nitra.

Schematizmus Nitrianskej diecézy. 2020. Schematizmus Nitrianskej diecézy 2020. Nitra.

Stárek, L'udovit. 1852. S. Ondrej Svorad (Zoerard) a Benedikt, ochráncovia biskupstva nitrianskeho. In Cyrill a Method I./1., 149.

Stránsky, Albert. 1933. Dejiny biskupstva nitrianskeho od najstarších dôb až do konca stredoveku. In Dejiny biskupstva nitrianskeho. Trnava.

Tkáčová Hedviga - Pavlíková Martina - Tvrdoň Miroslav - Prokopyev Alexey I. 2021. Existence and Prevention of Social Exclusion of Religious University Students due to Stereotyping. In Bogoslovni Vestnik 81/1, 199-223.

Tomko, Jozef. 1991. Odkaz slovenskému národu a spoločenstvám. Bratislava.

Vurum, Jozef. 1835. Episcopatus Nitriensis eiusquie Praesulum memoria. Bratislava.

Vragaš, Štefan (ed.). 1991. Život Konštantína-Cyrila a Život Metoda. Martin.

prof. ThDr. Viliam Judák, PhD.

Comenius University in Bratislava

Faculty of Roman Catholic Theology of Cyril and Methodius

Kapitulská 26

81458 Bratislava

Slovakia

judak1@uniba.sk 